\title{
DESIGN AND DEVELOPMENT OF MORSE LEARNING SYSTEM APPLICATION BASED ON VISUAL BASIC
}

\author{
Bayu Wibisono, Alexander Victor Bukit, Adi Bandono, Edy Widodo \\ D-3 Informatics Engineering, Indonesian Naval Technology College \\ www.sttal.ac.id
}

\begin{abstract}
School of Communication (Sekom) is a place for educational institutions of the Indonesian Navy's National Army which has the duty to educate and prepare human resources in the field of communication. In providing Morse gesture learning material, the instructors still use the media in the form of a Morse knock tool manually, the news is received and recorded by other students with a sheet of paper or a book. There are ideas or ideas from the author to combine the Morse signal method using computer media in its implementation. The design of this study was carried out to provide an overview of the system to be created. The flow of news delivery is news that is processed in the server and then sent using the computer as a server automatically so that it will come out in the form of morse audio after the process begins and then is received by students using a computer as a client and the results of student answers will be automatically saved into the server, after saving the teacher can retrieve the results directly typing students who automatically have a value that is managed in the server. The assessment system is automatically processed in the server by means of a comparison between the news sent by the teacher with the results typed by students.
\end{abstract}

Keywords: Morse, Server and client.

\section{INTRODUCTION}

\subsection{Background}

The School of Communication (Sekom) is a place of the Navy's educational institutions which has the duty to educate and prepare human resources in the field of communication. There are several educational programs in the School of Communication, including Dikspespa Communications, Communication Diktukba, Communication Communication, and Communication Communication. As for one of the material taught and given to students in the School of Communication is a Morse signal, this material is a basic material that must and must be mastered by every student.In providing Morse cue learning material, the teachers at the School still use the media in the form of a Morse knock tool manually. Teaching and learning activitiesare carried out inside or outside the room, where the instructor or student sends news using Morse knockers, the news is received and recorded by other students with a sheet of paper or a book. There are ideas or ideas from the author to combine the Morse signal method using computer media in its implementation.

Based on the problems mentioned above, then the design of the Morse sign learning system was built at the School of Communication, wherein the design of this learning media was computerized based which could be used in room / keymorse room, as well as in the management of instructional materials Morse instructors teachers can add, change and save material into a database. The design of the Morse sign learning system is expected to maximize the teaching and learning process of the School of Communication students and can help facilitate the instructor to prepare material to be given to students and learning activities an be done more easily and effectively. 


\subsection{Problem Formulation}

Based on the background of the problem above, then the problem can be formulated, namely how to design a Morse sign learning system in Visual Basic based Communication School (Sekom)?

\subsection{Research Objectives}

The purpose of this study is to design a Morse sign learning system, which can support and assist the process of learning the acceptance and delivery of Morse cues in the School of Communication.

\subsection{Research Benefits}

The benefits of this research are as follows:

a. For student :

1) Make it easier for students to practice sending and receiving news and training students to receive Morse news using computers.

2) To stimulate and foster enthusiasm and interest in student learning in accepting Morse cues.

3) Introducing students to learning systems using computers so they can keep up with current developments and technological advancements.

b. For teachers:

1) Make it easier for teachers to provide material so that the time spent is more effective and efficient.

2) Assist the teacher in introducing the delivery and receiving of Morse signal news systems using a computer.

\subsection{Limitation of Problems} follows:

Limitation problems in this study are as

a. Not discussing the signal communication procedure of the flag hoop and the semaphore flag in the Indonesian Navy.

b. Not discussing the Morse-ray signal communication procedure in the Navy. c. This application is only used as a learning tool for student learning systems in the Navy's communications school.

\section{LITERATURE REVIEW}

\subsection{Theoretical Basis}

Morse signaling is a method of sending and receiving where the method presents letters, numbers and punctuation into dot / dot (.) And dash / line (-) codes. Morse cues were created by Samuel Finley Breese Morse in the United States in 1830, in the first application of Morse cues used to send news using telegraph. This is related to the security of news because Morse itself is one of the security of news. Because Morse works by replacing the original text with Morse code so that Morse is better known as Morse code.

With the development of innovation and technology in sending news based on Morse code, so as to create some media that can be used in sending Morse cues, here are some media that used news with Morse telegraph cues.

Morse sign learning requires sensitivity and accuracy to what is heard, so the Morse code must and must be memorized by every student of the School of Communication. Learning Media Function.

The functions of this learning media include the following:

1) Create an effective and efficient learning situation.

2) As a means to meet learning needs.

3) Improve the quality of education.

4) Assist students or students in understanding the material provided.

5) Can present information that is still related to the material to be taught to students.

6) Motivate students to learn the material provided.

\subsubsection{Hosting}

Hosting is a place or internet service for making web pages made online and accessible to others. Whereas Hosting itself is an Internet service that provides resources for renting servers and allows organizations or individuals to display information on the internet in the form 
of HTTP, FTP, EMAIL or DNS. Server hosting consists of a combination of servers or a server connected to a high-speed internet network.

Types of hosting services available are shared hosting, VPS or Virtual Dedicated Servers, dedicated servers, colocation servers.

\subsubsection{Database}

A database is a fact about objects, people and others so that a data can be expressed with a value (numbers, rows of characters, or symbols). Data is used to express the values contained in the database, while the information is used to express a meaning of value when understood by its users. Information can be interpreted as data that has been organized in a form that is in accordance with the needs of users or users.

The database is a very important aspect in information systems where the database is a data storage repository that will be processed further, so that it can avoid duplicate data, the relationship between an unclear data and very complicated data updates. Morse database has several tables namely rank tables, teacher tables, teacher account tables, participant tables, participant account tables, exam tables, exam value tables, material tables, and material grades tables.

\subsubsection{Relationships between Tables}

Relationships between tables include:

a. Rank tables can be related to instructor tables and participant tables.

b. The instructor table can be related to the rank table, exam table, material table, teacher account table, exam value table and material value table.

c. The teacher account table can be related to the teacher table.

d. The participant table can be related to the participant's account table, rank table, material grades table and exam grades table.

e. The participant account table can be related to the participant table.

f. The exam table can be related to the material table, exam score table and teacher table. g. The exam score table can be related to the exam table, material table, participant table and teacher table.

h. Material table can be related to material value table, exam table, exam value table and teacher table.

i. The table of material values can be related to the material table, the teacher table and the participant table.

\section{RESEARCH METHODS}

\subsection{Research Design}

In the background of the problem, it has been explained that in the process of learning Morse cues for students, currently still using manual Morse knocking tools, besides that it also has not used the development of computerized Morse sign learning media.

Based on the description above, then designed a Morse gesture learning media based on Visual Basic so that it can support Morse sign learning activities. It is hoped that the design of the Morse cues learning media can be used as a Morse cues learning media for students to support teaching and learning activities.

\subsection{Research Procedure}

The research procedure is the stage of studying the system based on the results of a survey of existing problems, the results of the data obtained are processed to get a picture of document flow from the Morse cues learning system that occurs at this time. The flow of the data is the teacher gives question material which is then sent to students using Morse cues, then the material is answered by students on a paper answer sheet, the results of the answers to material questions are collected to the instructor to be assessed and the assessment results are submitted to the Communication School staff for recap. The following is an overview of the draft document flow process send and receive news with Morse cues.

\subsubsection{Time and Place}

The time and place of research when Communication School students carry out the practice of sending and receiving Morse cues in the Navy Naval Communication School (Sekom) Kodikopsla Kodiklatal Ujung Surabaya. 


\subsubsection{Tools and Materials}

The tool used is using knock and send equipment Morse cues, computers / laptops, and other supporting tools.

\subsubsection{Research Design}

The research design is carried out after an analysis of the system, which in the design of this system can provide an overview of the system to be made. The flow of news delivery is news that is processed in the server and then sent automatically so that it will come out in the form of audio sound and then accepted by students and the results of student answers will be saved automatically into the server, after saving the teacher can take the results of each student's answer that has entered into server, the grading system is also automatically processed on the server with a comparison between the news sent by the teacher and the results of typing from students.

\section{ANALYSIS AND DISCUSSION}

\subsection{Analysis of Data and Research Results}

\subsubsection{Analysis}

Design analysis in this study was carried out to provide an overview of the system to be made. The flow of news delivery is news that is processed in the server and then sent using the computer as a server automatically so that it will come out in the form of morse audio after the process is started then received by students using the computer as a client and the results of student answers will be stored automatically into the server, after saving the teacher can retrieve the results directly typing students who automatically have a value that is managed in the server. The assessment system is automatically processed in the server by means of a comparison between the news sent by the teacher with the results typed by students.

In the analysis of this design the author makes the design of the interface which is a design of the appearance of the system on a computer, where the design is made to facilitate interaction between the user and the system created. The design of Morse sign learning system consists of two interface design designs namely design for the server and design for the client.

\subsubsection{Assessment}

The grading system used in this application is to use an array system, an array is a group of variables that have the same data type and are declared with the same name. Array is an important concept in programming, because arrays make it possible to store data and object references in large quantities and indexed. Arrays use an integer index to determine the order of their elements, where the first element starts at index 0 , the second element has index 1, and so on. Declare an array variable with the desired data type in almost the same way as a normal variable. Array has a fixed size in the sense that it cannot enlarge or decrease its size after it is defined. Once defined, a variable named number can store 5 integer values that can be accessed through index 0 to index 4 . After defining the array, memory is allocated to store data from the array. The amount of memory allocated depends on the data type of the array variable and the number of array elements defined.

\subsubsection{Implementation}

In this implementation the author will explain the system used and its tools in the use of visual basic Morse sign based learning system which aims to facilitate the learning system of communication school students to be even better.

\subsubsection{Implementation of The System}

The device specifications used in the implementation of the visual basic Morse learning system application are divided into two, namely hardware and software. The details can be explained as follows:

\section{a. Hardware}

Hardware is a physical component of equipment that forms a system called a computer. The hardware to be used must have a good performance, so that the applications that are available can be accessed properly as well. The hardware needed in implementing visual basic Morse sign based learning system is as follows:

1) The server used in this design a) Operating System: Windows $7 /$ Windows 10, 32/64 Bit.

b) Processor: Intel (R) core (TM) i3 $2310 \mathrm{M}, 2.10 \mathrm{GHz}$. 
c) RAM: Minimum 2GB, Harddisk: $500 \mathrm{MB}$.

2) Client used in this design

a) Operating System: Windows $7 /$ Windows 10, 32/64 Bit.

b) Processor: Intel (R) core (TM) i3 $2310 \mathrm{M}, 2.10 \mathrm{GHz}$.

c) RAM: Minimum 2GB, Harddisk: $500 \mathrm{MB}$.

\section{b. Software}

Software is a program that is needed to run an application. The software needed in making this Morse sign learning system is as follows:

1) Visual basic 2010 Express.

2) Database MySql (XAMPP / PhpMyAdmin).

\subsubsection{Explanation of Program Use}

Morse gesture learning system application based on visual basic after the design stage is complete, the next stage is the implementation phase on the system created. during the system implementation phase, the system will be explained in detail. Morse gesture learning system application based on visual basic is a Desktop-based application and uses a clientserver local network (LAN). In this visual basic Morse gesture learning system application is divided into two programs namely server programs and client programs.

1) Program on the server

a) Login

Login also called "logon" is a term in terms of computer security, which is a process of entrance for users to access computer systems. Login is intended to set the identification process. In contrast to logout, the login process requires certain specific things. With the latest technology, the login process is increasingly tightened by hardware encryption, such as the fingerprint and retina eye scan process.

\subsection{Research Discussion}

\subsubsection{Testing}

The testing of Morse gesture learning media based on visual basic is done with the aim to find out the capability of the system that has been built in carrying out several processes. This system testing includes connection testing, ODBC testing and Morse signal delivery testing in the form of audio sound.

In testing this Morse signal aims to find out the data sent from the server computer can be received well on the client computer, especially the Morse audio sound and speed of delivery. In this test the first thing to do is to connect the internet first then we log in to the hosting that is already available.

\subsubsection{Results and Discussion}

Research on the design of Morse signbased learning system application programs based on visual basic is a type of applied research because this research aims to provide solutions and focus more on educational programs. This research can assist the task of the Surabaya navy communication school instructor in carrying out student teaching and learning activities, so that they can get better results and in accordance with what is expected. The visual basic Morse cues learning system application program uses the engineering method because this research applies science into an effective and efficient system design. This research was conducted based on organizational needs, especially in the implementation of student learning in communication schools. The system was built to accelerate the process of sending Morse news both classified and classified. With this system, related parties can easily and quickly in the process of sending Morse news by using an application that was made.

\section{CONCLUSIONS RECOMMENDATIONS}

AND

\subsection{Conclusions}

Based on the results of tests that have been carried out on the design and construction of visual basic-based Morse learning system applications, the following conclusions can be obtained: 
a. Morse gesture learning media is only used to train students in accepting Morse cues.

b. In sending news using this application the delivery speed can be adjusted and adjusted to the abilities of students.

c. Automatic assessment can be done using this Morse sign learning system application.

d. The output or results obtained can be used as a benchmark for teachers on the ability of each student to accept Morse cues.

\subsection{Recomendation}

a. From the results that have been achieved when designing a visual basic Morse learning system application based on this visual tested, for the future development of this visual basic Morse learning system application in order to send and receive both from server to client or vice versa.

b. For the learning process is made level or level, from the beginner, medium, and hard level which aims to differentiate the level of acceptance of Morse cues.

\section{REFERENCES}

bing.net. (1990). Semaphore flag signal props. indo: source, https://tse1.mm.bing.net.

blogspot.com. (1990). Morse whistle sound. indo: source, http://4.bp.blogspot.com.

HM, J. (2005). A structured approach to the theory and practice of business applications. yogyakarta: Andi offset Analysis and design of information systems.

Kadir, A. (n.d.). Database concepts and practical guidance. Yogyakarta: Andi.

kaskus.com. (1983). Manual Morse Knock Tool. indo: source, http://cdn.kaskus.com/images/2014/01/3 $1 / 5311983$

Kodiklatal, S. (1982). Student instruction package. Ujung, Surabaya: Sekomal. Laut, S. K. (n.d.). Student instruction tool package. Surabaya.
Manik pramata S, P. a. (March 11, 2015). Interactive learning media encoding morse and semaphore codes. PA 2012.

Sudarman, S. M. (June 2015). Human and computer interaction. Yogyakarta: Andi.

tse012.mm.bing.net. (1998). LAN (Local Area Network). indo: source, https://tse012.mm.bing.net.

tse2.mm.bing.net. (1985). Light beam signal aids. indo: source, https://tse2.mm.bing.net.

www.dakwatuna.com. (1993). Morse gesture with reflected sunlight. indo: source, https://i2.wp.com/www.dakwatuna.com.

yudianto, M. j. (April 2, 2015). Computer networks and their understanding. ilmukomputer.com.

(n.d.). (2012, February 29). Retrieved April 01, 2015, from the understanding of the database according to several.html: http://ummu hasanah.blogspot.com

8412860. (2015, April 01). Understanding, the type of database server. Retrieved April 01, 2015, from 8412860: http://www.academia.edu

Minarto, M., Majid, A., Ahmadi, A., \& Bukit, A. (2017). Rancang Bangun Aplikasi Sistem Pencatat Keluar Masuk Personel Di Penjagaan Sttal Surabaya Berbasis Rfid. International Journal Of ASRO STTAL, 8, 1-16. Retrieved from http://asrojournal-

sttal.ac.id/index.php/ASRO/article/view/ 223

Nanang, N., Bukit, A., \& Zulkifli, Z. (2017). Rancang Bangun Sistem Informasi Sintel Koarmatim Pada Aplikasi Security Clearance Berbasis Bluetooth Low Energy Dan Fingerprint. International Journal Of ASRO - STTAL, 8, 1-13. Retrieved from http://asrojournalsttal.ac.id/index.php/ASRO/article/view/ $\underline{225}$

Rozikin, C., Kurnianto, F., Ahmadi, A., \& Syaifi, M. (2018). Design Of Shooting Score 
Recording Information System Based On Image Processing. International Journal Of ASRO - STTAL, 9(1), 136141. Retrieved from http://asrojournalsttal.ac.id/index.php/ASRO/article/view/ $\underline{228}$

Sulistyono, E., Mahia, F., Bandono, A., \& Syahlan, Z. (2018). Design And Manufacture Of Indonesian Naval Warship Technical Condition Report And Inventory Information System. International Journal OF ASRO STTAL, 9(2), 133-140. Retrieved from http://asrojournal-

sttal.ac.id/index.php/ASRO/article/view/ 229

Jaya, I., Maryanto, E., Bukit, A., \& Zulkifli, M. (2018). Design And Development Of Early Heat Stroke Detection System In Military Cross Country Based On lot. International Journal Of ASRO - STTAL, 9(2), 141-151. Retrieved from http://asrojournal-

sttal.ac.id/index.php/ASRO/article/view/ 230 